\title{
Celiac Disease: A Short Overview about Immunological Aspects and Role of Microbiota
}

\author{
Dmitry Stakheev, Luca Vannucci* \\ Institute of Microbiology, Academy of Sciences of the Czech Republic, Videnska 1083, Prague 4, CZ \\ *Corresponding author: vannucci@ biomed.cas.cz \\ Received November 01, 2014; Revised November 05, 2014; Accepted November 11, 2014
}

\begin{abstract}
Coeliac disease is an illness of the small bowel that accounts multiple pathological aspects: malabsorption, chronic inflammation, autoimmunity. The altered response of the immune system to gluten and derived peptides is the central event. In this short review, we intend propose some aspects of the immunological network that may address to possible role of the microbiota in this pathology.
\end{abstract}

Keywords: coeliac disease, gluten, inflammation, Toll-like receptor 4, transglutaminase-2, microbiota

Cite This Article: Dmitry Stakheev, and Luca Vannucci, "Celiac Disease: A Short Overview about Immunological Aspects and Role of Microbiota.” International Journal of Celiac Disease, vol. 2, no. 4 (2014): 144-149. doi: 10.12691/ijcd-2-4-6.

\section{Introduction}

Coeliac disease $(\mathrm{CD})$ is an inflammatory disorder of the small intestine caused by inappropriate reaction of immune system to gluten/gliadin protein. $\mathrm{CD}$ is characterize by villous atrophy, crypt hyperplasia and increased number of immune cell of lamina propria. Also non-gut autoimmune injury of the skin, liver, brain, heart and other organs was described [1,2]. The main clinical manifestations of $\mathrm{CD}$, like diarrhea or malabsorption, appear to be reducing. Population studies showed that incidence of recognized symptomatic cases resulted around $1 \%$, while oligosymptomatic or asymptomatic unrecognized disease resulted to be much higher $(83 \%)([3,4]$, for a review about worldwide variation in the frequency see [5]). Untreated patients with oligo/asymptomatic CD appeared to have an increased risk for autoimmune disorders and hematological or small intestine cancers. On the other hand, patients with various types of autoimmune diseases such as type 1 diabetes, autoimmune thyroid disease, Sjögren disease and autoimmune liver disease were found to have an associated coeliac disease in a rate of $5-15 \%$ $[6,7]$. Coeliac disease was also found to constitute a risk in populations of patients presenting chromosomal abnormalities such as Down syndrome (trisomy 21) or Turner syndrome (45X0) [8,9]. Genetic bases of risk for $\mathrm{CD}$ have been identified. A positive correlation with HLA genotype DQ2 and DQ8 (DQ2.5, DQ8 and to a lesser degree DQ2.2) was proven, since all patients were positive for one of the two haplotypes. Gluten peptides have high affinity for these HLA molecules. Antigen presenting cells positive for HLA-DQ2- and HLA-DQ8 molecules efficiently present gluten peptides to CD4+ T-cells that develop a Th1 response leading to the tissue alterations seen in the coeliac disease $[10,11,12]$. However, not all HLA-DQ2 or
DQ8 subjects develop CD and further concurrent factors may activate the pathological process (e.g. intestinal microbiota, viral infections). Thus, the presence of these HLA molecules appear to be a major factor of risk for developing the illness than other factors like the timing of introduction of gluten in the diet of infants or the breast versus non-breast feeding [13].

\section{Coeliac Disease and Immune Response}

The damage of mucosal cells and alteration in permeability of the mucosal barrier allows gliadin (a fraction of gluten molecule), or even the unprocessed gluten molecule, to penetrate inside the mucosa and activate immune cells of innate and adaptive immunity (monocytes, macrophages natural killer (NK), dendritic cells, $\mathrm{CD}^{+} \mathrm{T}$ lymphocytes). The activation of the immune response is mediated by Toll-like (TLR) receptors and induces release of pro-inflammatory cytokines. Autoimmune reactivity against tissue transglutaminase 2 (TG2) is also present depending on production of specific immunoglobulins (anti-TG2IgA). The TG2IgA autoantibodies are used as a marker of coeliac disease and are found deposited in the bowel but also associated to extra-intestinal expressions of the illness. Tissue transglutaminase (TG) is an ubiquitous enzyme, calcium dependent, released from cells during inflammation. It can play a double role in the coeliac disease by increasing gluten-derived peptides with high affinity for the HLA-DQ2- and HLA-DQ8 molecules and by becoming target for autoimmune response. Tissue transglutaminase catalyzes post-translational modification of proteins. Glutamine-rich gliadin peptides are excellent substrates for TG2. This enzyme deamidate gliadin and generate negatively charged peptides (due to exhibition of glutamic acid residues) that have strong affinity for the HLA-DQ2 and HLA-DQ8 molecules. By this way, TG2 
can enhance the immunostimulatory effect of gluten $[7,14,15,16]$. On the other hand, deamidated gliadin peptides cross-linked to TG2 (gliadin-TG2-complexes) can be uptaken by antigen-presenting cells and presented to $\mathrm{CD} 4^{+} \mathrm{T}$ cells. This can elicit presentation of peptide from both molecules giving arise to immune responses against gliadin as well as against TG2 [17].

Recently, Iversen et all. (2013) reported that anti TG2IgA bind preferentially epitopes accessible to the open, $\mathrm{Ca}^{2+}$-activated enzyme conformation of the soluble enzyme but not of membrane-bound enzyme. In particular, two of the epitopes, overlapping with the fibronectin binding site in TG2, are not accessible when TG2 was bound to the cell surface. The Authors concluded that the autoantibodies are generated against the soluble, catalytically active enzyme, and explain the absence of autoantibodies against the membrane-bound form as consequent to negative selection of B cells recognizing membrane-bound self-antigens [18]. Zanoni et al. (2006) and Kagnoff et al. (1987) have proposed even further participation of the TG2IgA to the inflammatory process in coeliac disease. Discussing about TG2IgA activities and targets, these Authors outline how inflammation and autoimmunity might be elicited by these autoantibodies either by their direct interaction with immune receptors or by arising after viral infections via molecular mimicry. It was shown that anti-tTG2 IgA has cross-reactivity with human selfantigens heat shock protein 60 and TLR-4. Binding of last one by this antibody induces monocyte activation [19] Furthermore, the rotavirus major neutralizing protein VP-7 can be recognized by anti-tTG2IgA produced in the active phase of $\mathrm{CD}$, and, more recently, the early region Elb protein of human adenovirus serotype 12 was shown to have an amino acid sequence homology with A-gliadin. All of these findings indicate that even viruses might be involved in the pathogenesis of the $\mathrm{CD}$, possibly, through a mechanism of molecular mimicry [20].

Toll-like receptors are recognized to play important role in the immunological balance and defences in the gut mucosa [21]. Particular relevance has TLR-4. This TLR is a transmembrane glycoprotein with appartenence to the interleukin-1 receptor superfamily. It is a signaling pattern of recognition receptor detecting molecules expressed by invading microorganisms (e.g. lipopolysaccharides) for the protection of the host [22]. Modulation of TLR expression on intestinal epithelia was described in relation with the local microbial patterns [23,24]. The role of TLR4 in chronic inflammatory diseases, like IBD, was documented as well as in the development and progression of ovarian, breast, prostate and colorectal cancers [25]. Increased expression of TLR4 was found in patients with systemic lupus erythematous and coeliac disease suggesting a link with the pathogenesis of these illnesses [26]. Coeliac disease is not only a chronic inflammation but also an illness that deeply modify the immunological environment of the small intestine. In fact, despite the increased number of $\mathrm{T}$ lymphocytes in the intestinal mucosa, we can find lower T helper (Th1) cell proportion, and a prevalence of natural killer and NKT cells, FoxP3 positive T regulatory (Treg), myeloid dendritic cells and TLR-2 and TLR-4 positive monocytes in both adult and children patients with $\mathrm{CD}$ in comparison to healthy control in $[27,28]$. Moreover, in children with celiac disease the duodenal mucosa presents alterations in mRNA expression of TLRs
(TLR2 and TLR4), that result overexpressed [29]. Since epithelial and dendritic cells in the lamina propria of celiac subjects up-regulate their production of interleukin15 (IL-15), it was hypothesized that this cytokine may influence signaling properties of intraepithelial $\mathrm{CD}^{+}$. The same cytokine induces an increased expression of epithelial cell surface ligands, like major histocompatibility complex Class I polypeptide-related molecule A (MIC-A), ligand for NKG2D activating receptor of natural killer (NK) and CD8+ cytotoxic $\mathrm{T}$ lymphocytes (CTL). This altered expression can support epithelial changes and other pathological processes associated with celiac disease (e.g. refractory celiac disease Type 2 and enteropathy-associated T-cell lymphoma) [30,31,32].

Chronic intestinal inflammation is known as a factor increasing risk of cancer development [33]. TLR-4 plays a crucial role in colitis-associated neoplasia in mice [26,34]. Palova-Jelinkova et al. reported that chronic inflammatory enteropathy in CD might be due to IL- $1 \beta$ secretion by monocytes throw TLR4/MyD88 signaling pathway [35]. Nevertheless, according to recent studies, coeliac disease risk for cancer results slightly increased in comparison with general population but lower than the risk in IBDs. Lymphomas of the small bowel are the most frequent malignancies $[36,37]$.

\section{Gut, Microbiota and Coeliac Disease}

The gut represents a complex anatomical organ with a structure that allows not only digestion of aliments but also the relationship with the world outside our organism. In fact, microbiota altogether the thousands of molecules introduced with and derived from ingests (food, drugs, smoke, swollen pollution components from atmosphere) represent an extraordinary and continuous immunological challenge to the organism. To distinguish dangerous from tolerable agents, a very large accumulation of immune cells is widely homed and organized along the gut. They constitute the so-called GALT (gut associated lymphoid tissue), localized in the mucosa and the lamina propria. This makes the gut the largest site of immune cell localization in the organism, and a complex immunological organ. Especially developed and organized in the small and large bowel, it contributes to modulate our immune responses for the maintenance of the organism's homeostasis $[38,39]$. Such "homeostatic surveillance" is dependent on a close cross-talk of the immune cells with the mucosal cells and the commensal bacteria that since our birth colonize all our internal, as well as external, surfaces [40]. Especially in the last decade, it has become clearer that this cross-talk, modulated by the wide panel of different microbiota associated to the different environments present in the various districts of our body (and along the bowel), is a fundamental element for sustaining immunological, metabolic and neurologic functions of the organism, its adaptation to the general environmental conditions and for modulating the state of health, either protecting or predisposing to illnesses (from autoimmunity to cancer) [39,41,42,43].

The gut mucosa presents variations in structure and organization along the different tracts, including the immunological aspects $[44,45]$. They are in part associated to the different microbiota composition and the progressive higher density of bacteria from duodenum to distal colon [46]. However, metabolic characteristics of the mucosal 
cells altogether different selection of resident immune cells can make important differences in creating a tolerating environment to the microbiota and their metabolites. For example, it was found that the all-trans retinoic acid (RA), a metabolite of vitamin A with signaling via RA nuclear receptors, is involved in the small bowel immune homeostasis. RA appears required for establishing immune tolerance to dietary antigens in this tract of the gut by inducing gut-tropic $\mathrm{T}$ regulatory (Treg) cells expressing $\alpha 4 \beta 7^{+} \mathrm{CCR}^{+}$[47]. Differently, microbiota-specific Treg in the colon appear independent to RA, while they were found sensible to microbial metabolites like short-chain fatty acids (SCFA), that signal through the G proteincoupled receptor GPR43 [48]. This is in accordance to previous studies sustaining the importance of butyrate as a protective molecule for the colon homeostasis [49,50]. Moreover, Treg of the colon resulted to utilize another $\mathrm{G}$ protein-coupled receptor, GPR15, which is upregulated by SCFA, but not the CCR9 [48]. In such a way, the mechanisms of intestinal tolerance to dietary antigens appear to differ in the upper digestive tract from those that control tolerance to the microbiota in the large bowel, and they are complementary. This is an important issue when put in relation with the alteration of mucosal barrier that some bacteria can induce. In fact, other dietary and microbial metabolites can influence immune cell and gut homeostasis in the small and large bowel, e.g. the dietary ligands for aryl hydrocarbon receptor and microbiotamodified bile acids influencing the fat metabolic pathways [51,52]. Alteration in bile acid metabolism can be deleterious for the turn-over of mucosal cells by increasing apoptosis, facilitating leaking of mucosal barrier leading to activation of mucosal inflammation and selecting apoptosis-resistant cells with increase of cancer risk also by induced oxidative stress and DNA damage [53]. Consequently, the immunological responsiveness of the local environments may be affected by the microbiota through changes in production and concentration of metabolites influencing the survival of mucosal cells and their interconnection [54-59]. Under this prospective, alterations of microbiota balance or dysbiosis in the gut secondary to the use of antibiotics, a very common occurance, should be taken in consideration. Mårild K. et al. (2013) reported evidence of positive association between the use of antibiotics and subsequent appearance of CD (but also of lesions that may represent early CD), suggesting that intestinal dysbiosis may play a role in the pathogenesis of CD. Nevertheless, they also underlined that non-causal explanations about this positive association cannot be excluded and that further investigations should be conducted. Alterations of the mucous layer can influence the protective mechanisms in the mucosal barrier facilitating penetration of pathogens that elicit inflammatory responses with further damage of the barrier. The qualitative characteristics of the mucous along the bowel reflect the functional needs of each tract and represent selective environments for the resident microbiota. Commensal bacteria progressively increase their concentration from proximal to distal bowel. The progressive density of mucous from proximal to distal bowel contributes to isolate the progressively higher concentration of bacteria, impeding contact with the epithelial cells $[61,62]$.

When inflammation takes place, progressive disruption of intercellular connections can enhance the damage.
Alterations in the expression of claudin-2, claudin-3, claudin-4, claudin-8, occludin, zonulin-1 were found involved in the disruption of tight junctions in active coeliac disease as well as in active Crohn's disease biopsies, associated to mucosal translocation of bacteria and inflammation. $[63,64,65,66]$. It is also reported that gluten-free diet may reverse tight junction damage [67]. Thus, leaks in the mucosal barrier - as a consequence of dysbiosis, mucous alterations and primary immunological defects, override its protective function, permitting penetration of bacteria and antigens able to elicit inflammatory signals as well as dysregulation of Treg cells. T regulatory cells are considered to play a positive role in preventing inflammatory events in the gut mucosa. However, it is known that they can also sustain cancer development if a persistent inflammation takes place (like in the colitis due to inflammatory bowel diseases (IBD) as well as in the inflammatory microenvironment of sporadic cancer). In fact, the regulatory role of activated $\mathrm{T}$ reg cells $\left(\mathrm{Foxp}^{+}\right.$), exerted mainly through the release of immune suppressive and tissue-remodeling cytokine TGF- $\beta$, results detrimental for an effective anti-cancer immune response [68,69].

The establishment of an inflammatory process can be hypothesized as a pathological event producing similar effects along the gut mucosa, with possible support by the local microbiota as well as local anatomical and molecular conditions. However, this is not the real situation, according to the sites of chronic inflammation as well as of cancer development (especially adenocarcinoma). While we should expect the occurrence of mucosal cancer (adenocarcinoma) to be almost randomly distributed along the intestinal tract, a clear difference is found between the incidence of this type of cancer in the small bowel versus the large bowel. Small bowel cancers (including adenocarcinomas, lymphomas and sarcomas) represent around $2-3 \%$ of all gastrointestinal malignancies and only one third of them are adenocarcinomas [70,71]. The largest occurrence of cancer is in the large bowel with around $70 \%$ localization in the terminal tracts (sigmoid, rectum) even though some recent data indicate a certain increase of right sided cancers. Around 95\% are adenocarcinomas [72]. Colorectal cancers associated to IBD account for less than $2 \%$ of colon cancer cases yearly. In Crohn's disease patients the risk of developing cancer rises from $2 \%$ after 10 years of illness until $18 \%$ after 30 years. Similarly, on a period of 30 years, around $16 \%$ of the patients affected by ulcerative colitis can develop either pre-cancerous lesions or cancer of the colon [73]. In $\mathrm{CD}$ patients, instead, recent studies suggest a diminution of colorectal cancer occurrence. An explanation is given by impaired absorption and more rapid excretion of fat or fat-soluble agents (like hydrocarbons) avoiding their cocarcinogenic effects and possibly inducing changes in the microbial compartment [74,75].

A deeper investigation of the relationships between microbiome and affected mucosa would be desirable to open possible new avenues of intervention by the use of probiotics [76,77].

\section{Conclusions}

Coeliac disease is a complex illness in which the mucosal and systemic immunity are involved. The 
intestinal environment can play important role on the outcome of the malabsorption syndrome and its autoimmune reactivity. The lower incidence of cancers in the small bowel in comparison to large bowel, especially adenocarcinomas, suggests the existence of local factors that may influence the sensitivity of the mucosa to procarcinogenetic agents or conditions. Under this prospective, the level of local TLR-4 expression, the mucus constitution and the Treg cell responsiveness to environmental stimuli (as above cited) may play important roles together with type and variations of the microbiota in the different compartments of the bowel.

\section{Acknowledgement}

We like to thank RVO 61388971 (CZ); JILSKA, s.r.o, Prague (CZ); Manghi Czech Republic s.r.o, Prague (CZ); JANACKOVO NABREZI 25 s.r.o Prague (CZ); Studio Pierluigi Puccinelli, Viareggio (IT).

\section{References}

[1] Barton SH, Murray JA. Celiac disease and autoimmunity in the gut and elsewhere. Gastroenterol Clin North Am. 2008; 37: 411428.

[2] Lauret E, Rodrigo L. Celiac disease and autoimmune-associated conditions. Biomed Res Int. 2013; 2013: 127589.

[3] Pooran N, Brar P, Singh P, Green PH. Trends in the presentation of celiac disease. Am J Med. 2006; 119: 355. e9-14.

[4] Murray JA, Rubio-Tapia A. Diarrhoea due to small bowel diseases. Best Pract Res Clin Gastroenterol. 2012; 26: 581-600.

[5] Kang JY, Kang AH, Green A, Gwee KA, Ho KY. Systematic review: worldwide variation in the frequency of coeliac disease and changes over time. Aliment Pharmacol Ther. 2013; 38: 226245.

[6] Leffler D, Saha S, Farrell RJ. Celiac disease. Am J Manag Care. 2003; 9: 825-831.

[7] Husby S, Murray JA. Diagnosing coeliac disease and the potential for serological markers. Nat Rev Gastroenterol Hepatol. 2014; 11: 655-663.

[8] Mårild K, Stephansson O, Grahnquist L, Cnattingius S, Söderman G, Ludvigsson JF. Down syndrome is associated with elevated risk of celiac disease: a nationwide case-control study. J Pediatr. 2013; 163: 237-242.

[9] Bettendorf M, Doerr HG, Hauffa BP, Lindberg A, Mehls O, Partsch CJ, Schwarz HP, Stahnke N, Ranke MB. Prevalence of autoantibodies associated with thyroid and celiac disease in Ullrich-Turner syndrome in relation to adult height after growth hormone treatment. J Pediatr Endocrinol Metab. 2006; 19: 149154.

[10] Pallav K, Kabbani T, Tariq S, Vanga R, Kelly CP, Leffler DA. Clinical utility of celiac disease-associated HLA testing. Dig Dis Sci. 2014; 59: 2199-2206.

[11] Mubarak A, Spierings E, Wolters V, van Hoogstraten I, Kneepkens CM, Houwen R. Human leukocyte antigen DQ2.2 and celiac disease. J Pediatr Gastroenterol Nutr. 2013; 56: 428-430.

[12] Stepniak D, Koning F. Celiac disease--sandwiched between innate and adaptive immunity. Hum Immunol. 2006; 67: 460-468.

[13] Lionetti E, Castellaneta S, Francavilla R, Pulvirenti A, Tonutti E, Amarri S, Barbato M, Barbera C, Barera G, Bellantoni A, Castellano E, Guariso G, Limongelli MG, Pellegrino S, Polloni C, Ughi C, Zuin G, Fasano A, Catassi C; SIGENP (Italian Society of Pediatric Gastroenterology, Hepatology, and Nutrition) Working Group on Weaning and CD Risk. Introduction of gluten, HLA status, and the risk of celiac disease in children. N Engl J Med. 2014; 371: 1295-1303.

[14] Sollid LM. Molecular basis of celiac disease. Annu Rev Immunol. 2000; $18:$ 53-81.

[15] Di Sabatino A, Vanoli A, Giuffrida P, Luinetti O, Solcia E, Corazza GR. The function of tissue transglutaminase in celiac disease. Autoimmun Rev. 2012; 11: 746-753.
[16] Dørum S, Arntzen MØ, Qiao SW, Holm A, Koehler CJ, Thiede B, Sollid LM, Fleckenstein B. The preferred substrates for transglutaminase 2 in a complex wheat gluten digest are Peptide fragments harboring celiac disease T-cell epitopes. PLoS One. 2010; 5: e14056.

[17] Lindfors K, Mäki M, Kaukinen K. Transglutaminase 2-targeted autoantibodies in celiac disease: Pathogenetic players in addition to diagnostic tools? Autoimmun Rev. 2010; 9: 744-749.

[18] Iversen R, Di Niro R, Stamnaes J, Lundin KE, Wilson PC, Sollid LM. Transglutaminase 2-specific autoantibodies in celiac disease target clustered, $\mathrm{N}$-terminal epitopes not displayed on the surface of cells. J Immunol. 2013; 190: 5981-5991.

[19] Zanoni G, Navone R, Lunardi C, Tridente G, Bason C, Sivori S, Beri R, Dolcino M, Valletta E, Corrocher R, Puccetti A. In celiac disease, subset of autoantibodies against transglutaminase binds toll-like receptor 4 and induces activation of monocytes. PLoS Med. 2006; 3: e358.

[20] Kagnoff MF, Paterson YJ, Kumar PJ, Kasarda DD, Carbone FR, Unsworth DJ, Austin RK. Evidence for the role of a human intestinal adenovirus in the pathogenesis of coeliac disease. Gut. 1987; 28: 995-1001.

[21] Wagner H. Toll-like receptors in gastrointestinal diseases. Dig Dis. 2012; 30: 74-77.

[22] Hoshino K, Takeuchi O, Kawai T, Sanjo H, Ogawa T, Takeda Y, Takeda K, Akira S. Cutting edge : Toll -like receptor 4 (TLR4) deficient mice are hyporesponsive to lipopolysaccharide : evidence for TLR4 as the Lps gene product. J Immunol. 1999; 162 3749-3752.

[23] McClure R, Massari P. TLR-Dependent Human Mucosal Epithelial Cell Responses to Microbial Pathogens. Front Immunol. 2014; 5: 386

[24] Rakoff-Nahoum S, Paglino J, Eslami-Varzaneh F, Edberg S, Medzhitov R. Recognition of commensal microflora by toll-like receptors is required for intestinal homeostasis. Cell. 2004; 118: 229-241.

[25] Mai CW, Kang YB, Pichika MR. Should a Toll-like receptor 4 (TLR-4) agonist or antagonist be designed to treat cancer? TLR-4: its expression and effects in the ten most common cancers. Onco Targets Ther. 2013; 6: 1573-1587.

[26] Saito K, Katakura K, Suzuki R, Suzuki T, Ohira H. Modulating Toll-like receptor 4 signaling pathway protects mice from experimental colitis. Fukushima J Med Sci. 2013; 59: 81-88.

[27] Hmida NB, Ben Ahmed M, Moussa A, Rejeb MB, Said Y, Kourda $\mathrm{N}$, Meresse B, Abdeladhim M, Louzir H, Cerf-Bensussan N. Impaired control of effector $\mathrm{T}$ cells by regulatory $\mathrm{T}$ cells: a clue to loss of oral tolerance and autoimmunity in celiacdisease? Am J Gastroenterol. 2012; 107: 604-611.

[28] Cseh Á1, Vásárhelyi B, Szalay B, Molnár K, Nagy-Szakál D, Treszl A, Vannay Á, Arató A, Tulassay T, Veres G. Immune phenotype of children with newly diagnosed and gluten-free diettreated celiac disease. Dig Dis Sci. 2011; 56: 792-798.

[29] Eiró N, González-Reyes S, González L, González LO, Altadill A, Andicoechea A, Fresno-Forcelledo MF, Rodrigo-Sáez L, Vizoso FJ.Duodenal expression of Toll-like receptors and interleukins are increased in both children and adult celiac patients. Dig Dis Sci. 2012; 57: 2278-2285.

[30] Malamut G, El Machhour R, Montcuquet N, et al. IL-15 triggers an antiapoptotic pathway in human intraepithelial lymphocytes that is a potential new target in celiac disease-associated inflammation and lymphomagenesis. J Clin Invest 2010; 120: 2131-2143.

[31] Abadie V, Jabri B. IL-15: a central regulator of celiac disease immunopathology. Immunol Rev. 2014; 260: 221-234.

[32] Castillo NE, Theethira TG, Leffler DA. The present and the future in the diagnosis and management of celiac disease. Gastroenterol Rep (Oxf). 2014 Oct 17. pii: gou065. [in press]

[33] Foersch S, Neurath MF. Colitis-associated neoplasia: molecular basis and clinical translation. Cell Mol Life Sci. 2014; 71: 35233535.

[34] Fukata M, Shang L, Santaolalla R, Sotolongo J, Pastorini C, España C, Ungaro R, Harpaz N, Cooper HS, Elson G, KoscoVilbois M, Zaias J, Perez MT, Mayer L, Vamadevan AS, Lira SA, Abreu MT. Constitutive activation of epithelial TLR4 augments inflammatory responses to mucosal injury and drives colitisassociated tumorigenesis. Inflamm Bowel Dis. 2011; 17: 14641473.

[35] Palová-Jelínková L, Dáňová $K$, Drašarová $H$, Dvořák $M$, Funda DP, Fundová P, Kotrbová-Kozak A, Černá M, Kamanová J, 
Martin SF, Freudenberg M, Tučková L. Pepsin digest of wheat gliadin fraction increases production of IL-1 $\beta$ via TLR4/MyD88/TRIF/MAPK/NF- $\kappa$ B signaling pathway and an NLRP3 inflammasome activation. PLoS One. 2013; 8: e62426.

[36] Abdul Sultan A, Crooks CJ, Card T, Tata LJ, Fleming KM, West J. Causes of death in people with coeliac disease in England compared with the general population: a competing risk analysis. Gut. 2014 Oct 24. pii: gutjnl-2014-308285.

[37] Ilus T, Kaukinen K, Virta LJ, Pukkala E, Collin P. Incidence of malignancies in diagnosed celiac patients: a population-based estimate. Am J Gastroenterol. 2014; 109: 1471-1477.

[38] Nagler-Anderson C. Man the barrier! Strategic defences in the intestinal mucosa. Nat Rev Immunol. 2001; 1: 59-67.

[39] Tlaskalová-Hogenová H, Stěpánková R, Kozáková H, Hudcovic T, Vannucci L, Tučková L, Rossmann P, Hrnčír T, Kverka M, Zákostelská Z, Klimešová K, Přibylová J, Bártová J, Sanchez D, Fundová P, Borovská D, Srůtková D, Zídek Z, Schwarzer M, Drastich P, Funda DP. The role of gut microbiota (commensal bacteria) and the mucosal barrier in the pathogenesis of inflammatory and autoimmune diseases and cancer: contribution of germ-free and gnotobiotic animal models of human diseases. Cell Mol Immunol. 2011; 8: 110-120.

[40] Tlaskalová-Hogenová H, Farré-Castany MA, Stěpánková R, Kozáková H, Tucková L, Funda DP, Barot R, Cukrowska B, Sinkora J, Mandel L, et al. The gut as a lymphoepithelial organ: the role of intestinal epithelial cells in mucosal immunity. Folia Microbiol (Praha). 1995; 40: 385-391.

[41] Van Tyne D, Gilmore MS. A delicate balance: maintaining mutualism to prevent disease. Cell Host Microbe. 2014; 16(4): 425-427.

[42] Perrigoue J, Das A, Mora JR. Interplay of nutrients and microbial metabolites in intestinal immune homeostasis: distinct and common mechanisms of immune regulation in the small bowel and colon. Nestle Nutr Inst Workshop Ser. 2014; 79: 57-71.

[43] Vannucci L, Stepankova R, Grobarova V, Kozakova H, Rossmann P, Klimesova K, Benson V, Sima P, Fiserova A, TlaskalovaHogenova H. Colorectal carcinoma: Importance of colonic environment for anti-cancer response and systemic immunity. J Immunotoxicol. 2009; 6: 217-226.

[44] Zeitz M, Ullrich R, Schneider T, Schieferdecker HL, Riecken EO.Cell differentiation and proliferation in the gastrointestinal tract with respect to the local immune system. Ann N Y Acad Sci. 1994; 733: 75-86.

[45] Mowat AM, Agace WW. Regional specialization within the intestinal immune system. Nat Rev Immunol. 2014; 14: 667-685.

[46] Xie G, Lo CC, Scholz M, Chain PS. Recruiting human microbiome shotgun data to site-specific reference genomes. PLoS One. 2014; 9: e84963.

[47] Cassani B, Villablanca EJ, Quintana FJ, Love PE, Lacy-Hulbert A, Blaner WS, Sparwasser T, Snapper SB, Weiner HL, Mora JR. Gut-tropic $T$ cells that express integrin $\alpha 4 \beta 7$ and CCR9 are required for induction of oral immune tolerance in mice. Gastroenterology. 2011; 141: 2109-2118.

[48] Arpaia N, Campbell C, Fan X, Dikiy S, van der Veeken J, deRoos P, Liu H, Cross JR, Pfeffer K, Coffer PJ, Rudensky AY. Metabolites produced by commensal bacteria promote peripheral regulatory T-cell generation. Nature. 2013; 504: 451-455.

[49] Furusawa Y, Obata Y, Fukuda S, Endo TA, Nakato G, Takahashi D, Nakanishi Y, Uetake C, Kato K, Kato T, Takahashi M, Fukuda NN, Murakami S, Miyauchi E, Hino S, Atarashi K, Onawa S, Fujimura Y, Lockett T, Clarke JM, Topping DL, Tomita M, Hori S, Ohara O, Morita T, Koseki H, Kikuchi J, Honda K, Hase K, Ohno H. Commensal microbe-derived butyrate induces the differentiation of colonic regulatory T cells. Nature. 2013; 504: 446-450.

[50] Tedelind S, Westberg F, Kjerrulf M, Vidal A. Anti-inflammatory properties of the short-chain fatty acids acetate and propionate: a study with relevance to inflammatory bowel disease. World J Gastroenterol. 2007; 13: 2826-2832.

[51] Kiss EA, Vonarbourg C, Kopfmann S, Hobeika E, Finke D, Esser C, Diefenbach A. Natural aryl hydrocarbon receptor ligands control organogenesis of intestinal lymphoid follicles. Science. 2011; 334: 1561-1565.

[52] Sayin SI, Wahlström A, Felin J, Jäntti S, Marschall HU, Bamberg K, Angelin B, Hyötyläinen T, Orešič M, Bäckhed F. Gut microbiota regulates bile acid metabolism by reducing the levels of tauro-beta-muricholic acid, a naturally occurring FXR antagonist. Cell Metab. 2013; 17: 225-235.
[53] Bernstein H, Bernstein C, Payne CM, Dvorak K. Bile acids as endogenous etiologic agents in gastrointestinal cancer. World $\mathrm{J}$ Gastroenterol. 2009; 15: 3329-3340.

[54] Májer F, Sharma R, Mullins C, Keogh L, Phipps S, Duggan S, Kelleher D, Keely S, Long A, Radics G, Wang J, Gilmer JF. New highly toxic bile acids derived from deoxycholic acid, chenodeoxycholic acid and lithocholic acid. Bioorg Med Chem. 2014; 22: 256-268.

[55] Schulzke JD, Bojarski C, Zeissig S, Heller F, Gitter AH, Fromm M.Disrupted barrier function through epithelial cell apoptosis. Ann N Y Acad Sci. 2006; 1072: 288-299.

[56] Goswami P, Das P, Verma AK, Prakash S, Das TK, Nag TC, Ahuja V, Gupta SD, Makharia GK. Are alterations of tight junctions at molecular and ultrastructural level different in duodenal biopsies of patients with celiac disease and Crohn's disease? Virchows Arch. 2014; 465: 521-530.

[57] Cinova J, De Palma G, Stepankova R, Kofronova O, Kverka M, Sanz Y, Tuckova L. Role of intestinal bacteria in gliadin-induced changes in intestinal mucosa: study in germ-free rats. PLoS One. 2011; 6: e16169.

[58] Goto Y, Ivanov II. Intestinal epithelial cells as mediators of the commensal-host immune crosstalk. Immunol Cell Biol. 2013; 91: 204-214.

[59] Peterson LW, Artis D. Intestinal epithelial cells: regulators of barrier function and immune homeostasis. Nat Rev Immunol. 2014; 14: 141-153.

[60] Mårild K, Ye W, Lebwohl B, Green PH, Blaser MJ, Card T, Ludvigsson JF. Antibiotic exposure and the development of coeliac disease: a nationwide case-control study. BMC Gastroenterol. 2013; 13: 109.

[61] Swidsinski A, Sydora BC, Doerffel Y, Loening-Baucke V, Vaneechoutte M, Lupicki M, Scholze J, Lochs H, Dieleman LA. Viscosity gradient within the mucus layer determines the mucosal barrier function and the spatial organization of the intestinal microbiota. Inflamm Bowel Dis. 2007; 13: 963-970.

[62] Hansson GC.Role of mucus layers in gut infection and inflammation. Curr Opin Microbiol. 2012; 15: 57-62.

[63] Schulzke JD, Bojarski C, Zeissig S, Heller F, Gitter AH, Fromm M. Disrupted barrier function through epithelial cell apoptosis. Ann N Y Acad Sci. 2006; 1072: 288-299.

[64] Goswami P, Das P, Verma AK, Prakash S, Das TK, Nag TC, Ahuja V, Gupta SD, Makharia GK. Are alterations of tight junctions at molecular and ultrastructural level different in duodenal biopsies of patients with celiac disease and Crohn's disease? Virchows Arch. 2014; 465: 521-530.

[65] Cinova J, De Palma G, Stepankova R, Kofronova O, Kverka M, Sanz Y, Tuckova L. Role of intestinal bacteria in gliadin-induced changes in intestinal mucosa: study in germ-free rats. PLoS One. 2011; 6: e16169.

[66] Montalto M, Cuoco L, Ricci R, Maggiano N, Vecchio FM, Gasbarrini GImmunohistochemical analysis of ZO-1 in the duodenal mucosa of patients with untreated and treated celiac disease. Digestion. 2002; 65: 227-233.

[67] Pizzuti D, Bortolami M, Mazzon E, Buda A, Guariso G, D'Odorico A, Chiarelli S, D'Incà R, De Lazzari F, Martines D.Transcriptional downregulation of tight junction protein $\mathrm{ZO}-1$ in active coeliac disease is reversed after a gluten-free diet. Dig Liver Dis. 2004; 36: 337-341.

[68] Erdman SE, Rao VP, Olipitz W, Taylor CL, Jackson EA, Levkovich T, Lee CW, Horwitz BH, Fox JG, Ge Z, Poutahidis T. Unifying roles for regulatory $\mathrm{T}$ cells and inflammation in cancer. Int J Cancer. 2010; 126: 1651-165.

[69] Whiteside TL. The tumor microenvironment and its role in promoting tumor growth. Oncogene. 2008; 27: 5904-5912.

[70] Raghav K, Overman MJ. Small bowel adenocarcinomas--existing evidence and evolving paradigms. Nat Rev Clin Oncol. 2013; 10: 534-544.

[71] Piscaglia AC1, Campanale M, Gasbarrini G. Small bowel nonendocrine neoplasms: current concepts and novel perspectives. Eur Rev Med Pharmacol Sci. 2010; 14: 320-326.

[72] Rabeneck, L., Davila, J. A. \& El-Serag, H. B. Is there a true 'shift' to the right colon in the incidence of colorectal cancer? Am. J. Gastroenterol. 2003; 98: 1400-1409.

[73] Triantafillidis JK, Nasioulas, G, Kosmidis, PA. Colorectal cancer and inflammatory bowel disease: epidemiology, risk factors, mechanisms of carcinogenesis and prevention strategies. Anticancer research 2009; 29: 2727-2737. 
[74] Hugh J. Freeman. Adult Celiac Disease and Its Malignant Complications. Gut and Liver 2009; 3: 237-246.

[75] Zackular JP, Baxter NT, Iverson KD, Sadler WD, Petrosino JF, Chen GY, Schloss PD. The gut microbiome modulates colon tumorigenesis. MBio. 2013; 4: e00692-13.

[76] de Sousa Moraes LF, Grzeskowiak LM, de Sales Teixeira TF, Gouveia Peluzio Mdo C.Intestinal microbiota and probiotics in celiac disease. Clin Microbiol Rev. 2014; 27: 482-489.
[77] Duar RM, Clark K, Patil PB, Hernández C, Brüning S, Burkey TE, Madayiputhiya N, Taylor SL, Walter J. Identification and characterization of intestinal lactobacilli strains capable of degrading immunotoxic peptides present in gluten. J Appl Microbiol. 2014 Nov 6. [in press]. 